\title{
Physical methods for the treatment of fever in critically ill patients: a randomized controlled trial*
}

\author{
Métodos físicos para tratamento de febre em pacientes \\ críticos: ensaio clínico controlado randomizado \\ Métodos físicos para tratamiento de fiebre en pacientes \\ críticos: ensayo clínico controlado randomizado
}

Patrícia de Oliveira Salgado ${ }^{1}$, Ludmila Christiane Rosa da Silva², Priscila Marinho Aleixo Silva², Tânia Couto Machado Chianca $^{2}$

How to cite this article:

Salgado PO, Silva LCR, Silva PMA, Chianca TCM. Physical methods for the treatment of fever in critically ill patients: a randomized controlled trial. Rev Esc Enfem USP. 2016;50(5):823-830. DOI: http://dx.doi.org/10.1590/S0080-623420160000600016

* Extracted from the PhD dissertation "Uso de métodos físicos para tratamento do diagnóstico de enfermagem de hipertermia em pacientes adultos internados em ICU: ensaio clínico controlado randomizado", Escola de Enfermagem, Universidade Federal de Minas Gerais, 2014.

${ }^{1}$ Universidade Federal de Viçosa,

Viçosa, MG, Brazil.

${ }^{2}$ Universidade Federal de Minas Gerais, Escola de Enfermagem, Belo Horizonte, MG, Brazil.

\section{ABSTRACT}

Objective: To evaluate the effects of physical methods of reducing body temperature (ice pack and warm compression) in critically ill patients with fever. Method: A randomized clinical trial involving 102 adult patients with tympanic temperature $\geq 38.3^{\circ} \mathrm{C}$ of an infectious focus, and randomized into three groups: Intervention I - ice pack associated with antipyretic; Intervention II - warm compress associated with antipyretic; and Control - antipyretic. Tympanic temperature was measured at 15 minute intervals for 3 hours. The effect of the interventions was evaluated through the Mann-Whitney test and Survival Analysis. "Effect size" calculation was carried out. Results: Patients in the intervention groups I and II presented greater reduction in body temperature. The group of patients receiving intervention I presented tympanic temperature below $38.3^{\circ} \mathrm{C}$ at 45 minutes of monitoring, while the value for control group was lower than $38.3^{\circ} \mathrm{C}$ starting at 60 minutes, and those who received intervention II had values lower than $38.3^{\circ} \mathrm{C}$ at 75 minutes of monitoring. Conclusion: No statistically significant difference was found between the interventions, but with the intervention group I patients showed greater reduction in tympanic temperature compared to the other groups. Brazilian Registry of Clinical Trials: RBR-2k3kbq

\section{DESCRIPTORS}

Fever; Critical Care Nursing; Evidence-Based Nursing; Evaluation of Results of Therapeutic Interventions; Intensive Care Units. 


\section{INTRODUCTION}

Fever is a rise in body temperature that exceeds the normal daily variation and occurs in association with an increase in the hypothalamic set point, for example, going from $37^{\circ} \mathrm{C}$ to $39^{\circ} \mathrm{C}$. It refers to a defensive response of the body against pyrogenic agents released as part of an inflammatory process, causing increased immune response and protection of the human body against infectious agents ${ }^{(1)}$.

Due to the high risk of infection associated with invasive procedures, immunosuppression, pathological conditions and environmental risks present in intensive care units (ICU), fevers occur in more than one-third of critical patients ${ }^{(2)}$. It is therefore a frequent event in this type of unit, with over $50 \%$ of individuals admitted to ICU presenting fevers due to infectious or non-infectious causes ${ }^{(1,3)}$.

Literature indicates that due to hemodynamic instability that critical patients may present, fever is a symptom that should be eliminated or reduced with drug treatment, and should also be associated or not to physical methods with patients presenting this profile ${ }^{(2,4)}$. Therefore, the care of patients with fever demands a set of appropriate, specific and related care based on scientific evidence, however, little is known about the best provision of care. Despite this lack of knowledge in literature, implementing techniques to reduce body temperature is common in the clinical practice of feverish patients using antipyretics, physical methods or a combination of both ${ }^{(1,5)}$.

It is worth noting that pharmacological interventions to reduce body temperature can cause adverse effects such as hypotension, gastrointestinal bleeding, liver and kidney toxicity, in addition to increasing the length of hospitalization in the $\operatorname{ICU}^{(6)}$. Still, the use of physical methods in treating fever is controversial due to its propensity to induce peripheral vasoconstriction, tremors, sympathetic activation and discomfort in patients ${ }^{(1,7)}$.

There are several methods of externally cooling body temperature, but the most indicated are applying warm or cold compresses, a warm/lukewarm bath, using blankets with a cooling system and improving the circulation of air in the environment/room where the feverish patient is staying ${ }^{(1,5,8)}$. However, literature ${ }^{(1,5)}$ indicates that there is no consensus among experts about the most efficient and secure method of controlling body temperatures, especially when referring to those used on adult patients.

Given these considerations, in view of the high fever incidence in adult patients admitted to ICU and the scarce knowledge on the best nursing care provided to patients with this profile, we ask: Is the use of physical methods (ice pack and warm compress) associated with antipyretics more effective when compared to administering antipyretics alone in reducing the body temperature of adult patients with fever admitted to ICU?

This study aimed at evaluating the effect of applying physical methods (ice pack and warm compress) associated with administering an antipyretic in reducing the body temperature of patients with fever admitted to ICU. The hypotheses tested were: a reduction in body temperature of adult patients admitted to the ICU with tympanic temperature $\geq 38.3^{\circ} \mathrm{C}$ of an infectious focus, receiving physical methods (ice pack or warm compress) associated with the administration of an antipyretic is equivalent to that occurring in patients who only received an antipyretic; and a reduction in body temperature of adult patients admitted to the ICU with tympanic temperature $\geq 38.3^{\circ} \mathrm{C}$ of an infectious focus, and who received application of physical methods (ice pack or warm compress) associated with administration of an antipyretic is more effective than patients who only received administration of an antipyretic.

\section{METHOD}

An experimental, randomized controlled trial conducted in the period from June 18, 2012 to May 18, 2013, in two adult ICUs (a surgical unit and a clinic unit) of a large general hospital in a Brazilian capital city. Both have 10 beds, the same medical and nursing coordination, in addition to similar care practice protocols and clinical teams.

During the period from March $1^{\text {st }}$ to April $30^{\text {th }}, 2012$, a pilot study was conducted with 18 patients (six patients per group) in order to calculate sample size, test the data collection instrument and to train the data collection team. The pilot study found that the six patients who participated in the intervention group I had their temperature normalized at the end of the collection, while only four of the six who participated in intervention group II had their body temperature reduced. Thus, the success percentage of the intervention group II (67\%) was used for sample calculation. An absolute difference of the proportion of patients who improved to normal temperature was established between $14 \%$ and $32 \%$. In addition, based on the sample size of similar studies ${ }^{(8)}$, an absolute minimum difference between the treatment success proportion of $27 \%$ was established at a significance level of 5\% (type I error) and a test power of $80 \%$ (type II error). Thus, the sample consisted of 34 patients in each group, totaling 102 patients. We emphasize that the patients involved in the pilot study were not included in the final study sample.

For training the data collection team, a manual with guidelines was developed comprising information on $\mathrm{pa}^{-}$ tient assessment, using equipment/materials, applying treatments and recording data during treatment. Team members followed a work schedule to ensure that two of the (trained) members remained in the ICU on a daily basis for a period of 10 hours to collect the Clear and Informed Consent Form (TCLE) and to apply the intervention on patients that met the inclusion criteria.

Patients who presented tympanic temperature $\geq 38.3^{\circ} \mathrm{C}$ with an infectious focus and antipyretic administration time up to 20 minutes before treatment application were included. Those with severe heart disease, malignant hyperthermia, or those that would be submitted to any procedures during the next 3 hours such as central venous access and/or arterial access puncture, intra-hospital transport or bathing were excluded. It is worth noting that bathing is also an established physical method for reducing body temperature, however, this intervention was not included for evaluation in this study. 
Patients who comprised the sample were randomized into three groups: intervention group I (application of ice packs associated with antipyretic medication), intervention group II (application of warm compress associated with antipyretic medication) and control group (administration of antipyretic medication alone). A table with random numbers generated by the MiniTab program was used for randomization. Each number of the list with the sequences for Intervention Group I, II and Control were individually placed into an opaque envelope, sequentially numbered from 1 to 102 and sealed. These actions were carried out by an individual outside of the study. Upon identification of a patient who met the inclusion criteria, a team member proceeded to open the envelope, identified the treatment to be performed and proceeded to perform it. After, another researcher blinded to the information in the envelope, performed the data collection and recorded it in an instrument specially used for it.

A maximum time of 20 minutes elapsed between identifying a patient who met the inclusion criteria up until antipyretic administration (one $2 \mathrm{~mL}$ ampoule containing $1 \mathrm{~g}$ of dipyrone ${ }^{\circledR}$ of $500 \mathrm{mg} / \mathrm{mL}$, prescribed intravenously). For intervention groups I and II, the ice pack or warm compress, respectively, were applied immediately after antipyretic administration with a maximum interval of 2 minutes between medicine administration and applying the intervention. The prescribed antipyretic medication was administered intravenously only for the patients allocated in the control group. All patients only received one dose of the same medication during the monitoring period.

In Intervention I, application of an instant cold pack available in the Brazilian market (Calminex Ice Bag ${ }^{\circledR}$ ) was used. The disposable pack is composed of ammonium nitrate and water in a $15 \mathrm{~cm} \times 22 \mathrm{~cm}$ plastic package. After being activated by manual traction, the content temperature cools down to $-3.8^{\circ} \mathrm{C}$ for up to 40 minutes. For implementing Intervention II (warm compress), a mandatory $100 \%$ cotton operating field of $45 \mathrm{~cm}$ x $50 \mathrm{~cm}$ was used soaked in water at a temperature between 29 and $30^{\circ} \mathrm{C}$.

The ice pack and the warm compress were placed in the armpits and on the groin (one in each of the described regions) during 30 minutes with four ice packs or warm compresses being used per patient without rotation. Data were also collected at the time of treatment on sociodemographic and clinical variables, as well as the outcome variable (tympanic temperature).

A digital infrared ear thermometer (Baby Care ${ }^{\circledR}$ ) was used for measuring tympanic temperature. Researchers were trained to measure the temperature by centralizing the tip of the thermometer (with protective cover) in the ear, directing it to the tympanic membrane and pushing the thermometer in order to close the opening of the auditory canal ${ }^{(9)}$. Measuring the temperature of the tympanic membrane with the help of the tympanic thermometer is a non-invasive method for severely ill patients. The instrument measures the infrared radiation of the tympanic membrane emitted from the heat of the blood circulation. Its advantages are being easy to handle, and it provides fast and accurate results ${ }^{(10)}$.
Tympanic temperature was measured at 15-minute intervals during 3 hours from the moment of applying the intervention in all intervention groups. Tympanic temperature reduction was considered a value $<38.3^{\circ} \mathrm{C}$, as a patient hospitalized in the ICU in a fevered state is considered to have a body temperature $\geq 38.3^{\circ} \mathrm{C}^{(3)}$.

The ambient internal and external minimum and maximum temperature was monitored in the two units (ICU and surgical clinic) during all data collection using a model 7427.03.0.00 Incoterm ${ }^{\circledR}$ digital thermometer, and values were maintained between $24^{\circ} \mathrm{C}$ and $28^{\circ} \mathrm{C}$.

The data were processed in a database using the Statistical Package for the Social Sciences (SPSS) version 18.0 program. A descriptive analysis and association with the Chi-square and Kruskal-Wallis tests were conducted to analyze socio-demographic and clinical data, and according to the variable category under study.

Before the specific analyses, waste analysis with the Shapiro-Wilk normality and visual analysis of the variance of the residues were carried out to evaluate the homocedasticity. The waste analysis indicated that the assumptions were not valid, thus being the non-parametric test of MannWhitney to compare the effect of interventions I and II with the control group. In addition, with comparisons of 12 times it was necessary to use the Bonferroni correction for the significance level, with the value $\mathrm{p} \leq 0.004$ considered as significant. The Cox hazard model (risk) was used for the multivariate analysis.

The effect size of the intervention was determined by calculating the Hedges g, considering the following cut-off points: values greater than or equal to 0.8 represent large effect size; between 0.8 and 0.2 average, and less than 0.2 was small ${ }^{(11-12)}$.

The study was approved by the Research Ethics Committee (COEP) of the Federal University of Minas Gerais (CAAE no 0380.0.203.216-11).

\section{RESULTS}

108 patients were selected according to the eligibility criteria. However, among the 108 eligible patients, six were going to be subjected to sponge bath in the next 3 hours after reaching a body temperature $\geq 38.3^{\circ} \mathrm{C}$, which excluded them from the study according to the inclusion criteria.

Among the 102 patients included in the study, 34 received an ice pack application associated with antipyretic medication (Intervention I), 34 received a warm compress associated with antipyretic medication (Intervention II), and 34 only received antipyretic (control). There were no losses of patients during monitoring. Patient distribution is presented in Figure 1.

Data concerning sociodemographic and clinical variables of patients included in the study are shown in Table 1.

Regarding age, the results of the Kruskal-Wallis tests show that the randomization of patients in each group was adequate, the groups were similar, and there was no statistical difference in the effect of the interventions tested among different age groups. 


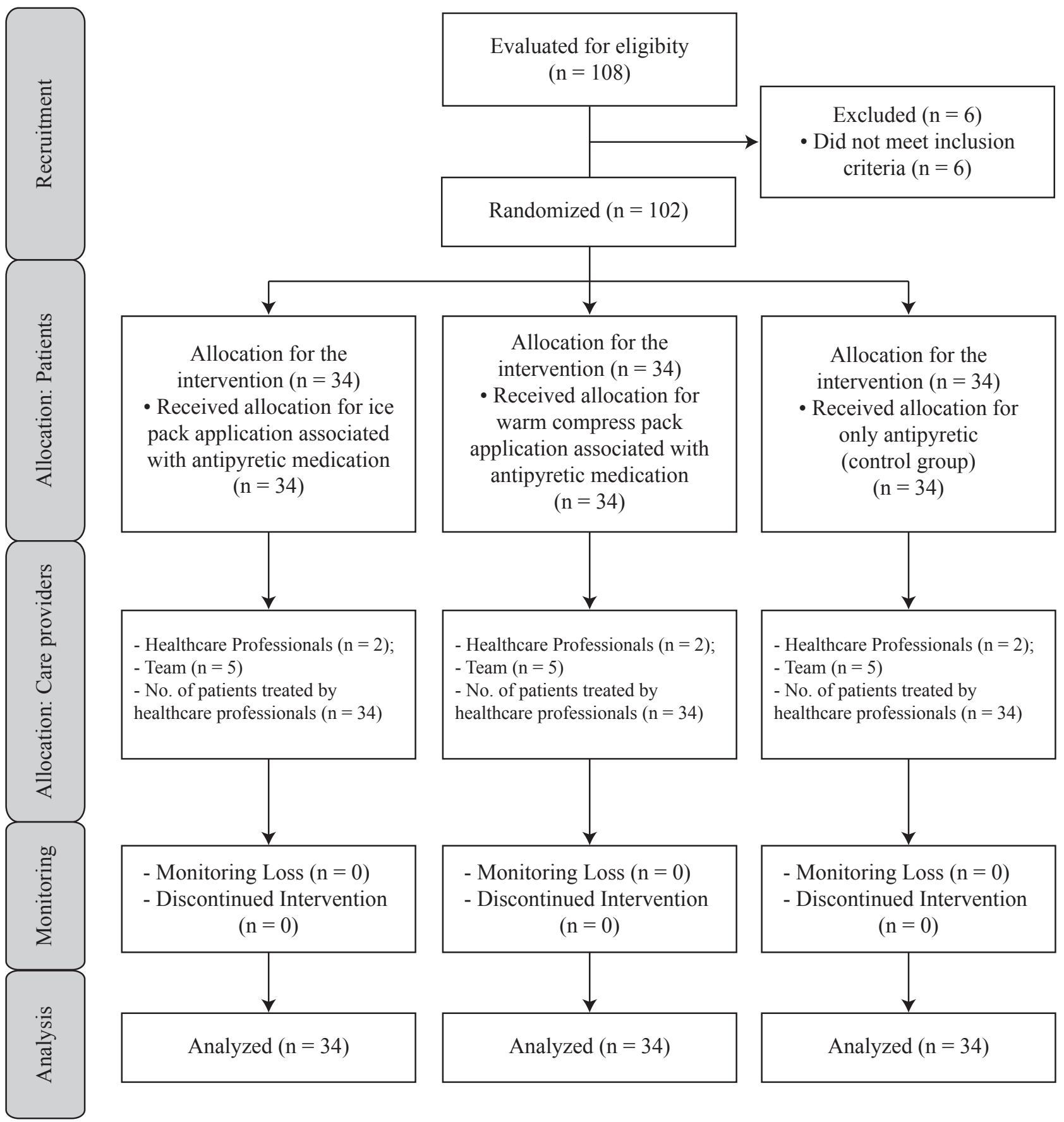

Figure 1 - Flowchart of study participants: initial and final inclusion - Belo Horizonte, MG, Brazil, 2013.

Even with randomization, it was found that the control group showed an advantage over the others, as the initial temperature of the patients was lower. However, in evaluating the difference between the initial and the final temperatures per group, it was found that patients from Intervention Group I and also those of Intervention II showed a greater reduction in body temperature. Patients allocated to the control group had a reduction in temperature of $0.7^{\circ} \mathrm{C}$, while Intervention Group I and also Intervention II presented a reduction of $0.9^{\circ} \mathrm{C}$ between the initial and final temperatures. It was also found that from 45 minutes of monitoring, Intervention I group presented a tympanic temperature below $38.3^{\circ} \mathrm{C}$ and the control group showed a temperature lower than $38.3^{\circ} \mathrm{C}$ from 60 minutes of monitoring. Intervention Group II presented a lower value than $38.3^{\circ} \mathrm{C}$ with 75 minutes of monitoring. It was observed that there was no statistically significant difference in the effect of implementing physical methods associated with antipyretic to reduce tympanic temperature (Table 2).

Variability in tympanic temperature was found in patients of all groups with a reduction over time. Patients allocated to Intervention Group I (received ice packs associated with antipyretic) showed a greater reduction in temperature values from baseline up to 180 minutes (Figure 2). 
Table 1 - Characterization of patients according to the randomized groups - Belo Horizonte, MG, Brazil, 2013.

\begin{tabular}{|c|c|c|c|c|}
\hline \multirow[t]{2}{*}{ Variables } & $\begin{array}{c}\text { Intervention I } \\
\quad \mathrm{n}=\mathbf{3 4}\end{array}$ & $\begin{array}{c}\text { Interven- } \\
\text { tion II } \\
n=34\end{array}$ & $\begin{array}{l}\text { Control } \\
n=34\end{array}$ & \multirow[t]{2}{*}{$p$-value } \\
\hline & $\mathbf{N}$ & $\mathbf{N}$ & $\mathbf{N}$ & \\
\hline Gender n (\%) & & & & $0.066^{*}$ \\
\hline Male & $24(71 \%)$ & $25(74 \%)$ & $\begin{array}{c}15 \\
(44 \%)\end{array}$ & \\
\hline Female & $10(29 \%)$ & $9(26 \%)$ & $\begin{array}{c}19 \\
(56 \%)\end{array}$ & \\
\hline \multicolumn{2}{|c|}{ Admission type n (\%) } & & & $0.509^{*}$ \\
\hline Surgical & $11(32 \%)$ & $5(19 \%)$ & $\begin{array}{c}10 \\
(31 \%)\end{array}$ & \\
\hline Clinic & $23(68 \%)$ & $21(81 \%)$ & $\begin{array}{c}24 \\
(69 \%)\end{array}$ & \\
\hline \multicolumn{2}{|c|}{ Hospitalization Site n (\%) } & & & $0.547^{*}$ \\
\hline Surgical ICU & $7(21 \%)$ & $7(27 \%)$ & $\begin{array}{c}11 \\
(32 \%)\end{array}$ & \\
\hline Clinical ICU & $27(79 \%)$ & $19(73 \%)$ & $\begin{array}{c}23 \\
(68 \%)\end{array}$ & \\
\hline Outcome n (\%) & & & & $0.937^{*}$ \\
\hline Discharge & $21(65 \%)$ & 15 & 21 & \\
\hline Death & $13(35 \%)$ & 11 & 13 & \\
\hline $\begin{array}{l}\text { Age in years } M \\
\text { (SD) }\end{array}$ & $51(16)$ & $54(16)$ & $55(16)$ & $0.119^{* *}$ \\
\hline $\begin{array}{l}\text { Length of stay } \\
\text { in days } M(S D)\end{array}$ & $58(111)$ & $44(24)$ & $37(28)$ & $0.469^{* *}$ \\
\hline
\end{tabular}

Legend: "Chi-square Test; "Kruskal-Wallis Test. Acronyms: mean (M); standard deviation $(\mathrm{SD})$.
After 3 hours of monitoring, it was found that the 34 patients allocated to Intervention Group I presented reduced tympanic temperature compared to baseline. Among the 34 patients allocated to Intervention Group II, only two (6\%) did not present a reduction in tympanic temperature. In turn, at the end of monitoring, four (12\%) of the 34 patients allocated to the control group did not present a reduction in tympanic temperature.

In the Cox regression analysis, it was found that the effect of Intervention I was 1.4 times higher compared to the control group in reducing tympanic temperature; however, a statistically significant difference was not found for either Intervention I ( $p=0.19$ ) or for Intervention II $(\mathrm{p}=0.41)$.

Effect size for Intervention I had an average magnitude $(\hat{\mathrm{g}}=0.4)$, whereas it had a small magnitude for Intervention II ( $\hat{\mathrm{g}}=0.17)$.

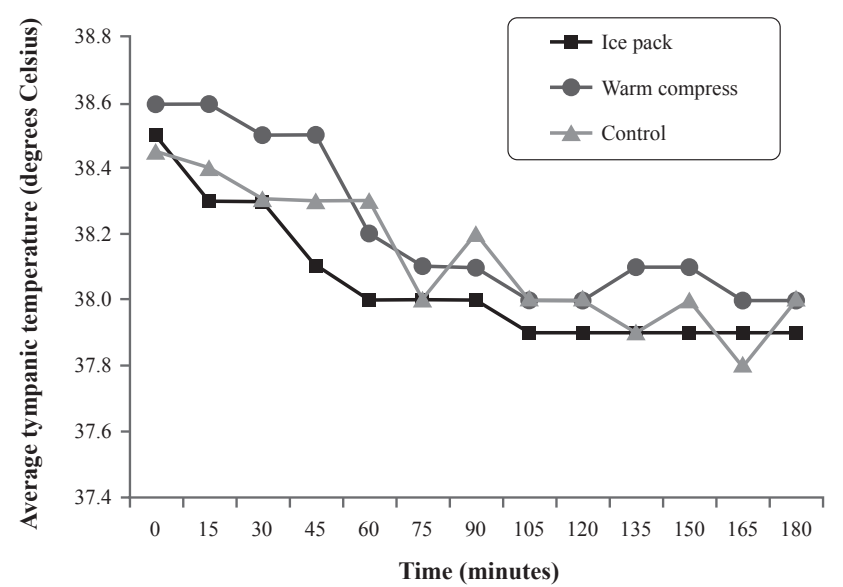

Figure 2 - Median of tympanic temperature in each assessment, according to the randomized groups $(n=102)$ - Belo Horizonte, MG, Brazil, 2013.

Table 2 - Evaluation of temperature at each measurement time by intervention group - Belo Horizonte, MG, Brazil, 2013.

\begin{tabular}{|c|c|c|c|c|c|c|c|c|c|}
\hline \multirow{2}{*}{ Time (minutes) } & \multirow{2}{*}{ Group } & \multicolumn{8}{|c|}{ Tympanic Temperature } \\
\hline & & $\mathbf{N}$ & Mean & $\mathrm{SD}^{*}$ & Minimum & Median & Maximum & $\mathrm{Cl} 95 \%{ }^{* *}$ & $\mathbf{p}^{* * *}$ \\
\hline \multirow{3}{*}{ Baseline } & Control & 34 & 38.6 & 0.3 & 38.3 & 38.5 & 39.5 & $38.3-38.7$ & \\
\hline & Intervention I & 34 & 38.7 & 0.6 & 38.3 & 38.5 & 41.1 & 38.4-38.6 & 0.69 \\
\hline & Intervention II & 34 & 38.9 & 0.6 & 38.3 & 38.6 & 40.1 & 38.4-39.1 & 0.03 \\
\hline \multirow{3}{*}{15} & Control & 33 & 38.4 & 0.5 & 37.5 & 38.4 & 39.7 & $38.1-38.6$ & \\
\hline & Intervention I & 34 & 38.5 & 0.8 & 37.3 & 38.3 & 41.1 & $38.0-38.7$ & 0.64 \\
\hline & Intervention II & 34 & 38.7 & 0.6 & 37.6 & 38.6 & 40.1 & $38.3-38.8$ & 0.11 \\
\hline \multirow{3}{*}{30} & Control & 33 & 38.4 & 0.6 & 37.3 & 38.3 & 39.9 & $38.0-38.7$ & \\
\hline & Intervention I & 33 & 38.3 & 0.8 & 36.8 & 38.3 & 40.7 & $37.8-38.6$ & 0.46 \\
\hline & Intervention II & 34 & 38.6 & 0.8 & 36.8 & 38.5 & 40.5 & $38.1-38.8$ & 0.36 \\
\hline \multirow{3}{*}{45} & Control & 33 & 38.3 & 0.7 & 36.3 & 38.3 & 39.6 & $38.0-38.5$ & \\
\hline & Intervention I & 33 & 38.1 & 1 & 36.0 & 38.1 & 40.7 & $37.6-38.5$ & 0.27 \\
\hline & Intervention II & 34 & 38.5 & 0.8 & 36.2 & 38.5 & 40.4 & $38.1-38.8$ & 0.21 \\
\hline
\end{tabular}




\begin{tabular}{|c|c|c|c|c|c|c|c|c|c|}
\hline \multirow{2}{*}{ Time (minutes) } & \multirow{2}{*}{ Group } & \multicolumn{8}{|c|}{ Tympanic Temperature } \\
\hline & & $\mathbf{N}$ & Mean & $\mathrm{SD}^{*}$ & Minimum & Median & Maximum & $\mathrm{Cl} 95 \%{ }^{* *}$ & $\mathbf{p}^{* * *}$ \\
\hline \multirow{3}{*}{60} & Control & 33 & 38.2 & 0.7 & 36.6 & 38.3 & 39.7 & $38.0-38.6$ & \\
\hline & Intervention I & 33 & 38.0 & 1 & 35.5 & 38.0 & 40.7 & $37.6-38.3$ & 0.1 \\
\hline & Intervention II & 33 & 38.3 & 0.7 & 36.8 & 38.2 & 40.6 & $38.0-38.6$ & 0.95 \\
\hline \multirow{3}{*}{75} & Control & 33 & 38.1 & 0.8 & 36.1 & 38.0 & 39.6 & $37.8-38.5$ & \\
\hline & Intervention I & 33 & 38.0 & 1 & 35.3 & 38.0 & 40.7 & $37.6-38.1$ & 0.46 \\
\hline & Intervention II & 33 & 38.2 & 0.7 & 36.5 & 38.1 & 40.7 & $37.9-38.6$ & 0.49 \\
\hline \multirow{3}{*}{90} & Control & 33 & 38.1 & 0.8 & 36.2 & 38.2 & 39.8 & $37.8-38.5$ & \\
\hline & Intervention I & 33 & 38.0 & 0.9 & 36.0 & 38.0 & 40.9 & $37.7-38.2$ & 0.34 \\
\hline & Intervention II & 33 & 38.2 & 0.8 & 36.9 & 38.1 & 40.6 & $37.7-38.4$ & 0.92 \\
\hline \multirow{3}{*}{105} & Control & 33 & 38.0 & 0.9 & 35.1 & 38.0 & 40.1 & $37.8-38.5$ & \\
\hline & Intervention I & 32 & 37.9 & 0.9 & 35.3 & 37.9 & 40.7 & $37.8-38.2$ & 0.41 \\
\hline & Intervention II & 33 & 38.2 & 0.9 & 36.8 & 38.0 & 40.9 & $37.8-38.5$ & 0.81 \\
\hline \multirow{3}{*}{120} & Control & 33 & 38.0 & 0.9 & 35.0 & 38.0 & 39.9 & $37.8-38.4$ & \\
\hline & Intervention I & 32 & 37.9 & 0.9 & 35.8 & 37.9 & 40.6 & $37.7-38.2$ & 0.36 \\
\hline & Intervention II & 33 & 38.2 & 0.9 & 37.0 & 38.0 & 40.9 & $37.6-38.5$ & 0.91 \\
\hline \multirow{3}{*}{135} & Control & 33 & 38.0 & 1 & 35.0 & 37.9 & 39.0 & $37.5-38.2$ & \\
\hline & Intervention I & 32 & 37.9 & 0.9 & 35.3 & 37.9 & 30.0 & $37.6-38.2$ & 0.55 \\
\hline & Intervention II & 33 & 38.2 & 0.9 & 36.8 & 38.1 & 40.4 & $37.8-38.4$ & 0.77 \\
\hline \multirow{3}{*}{150} & Control & 33 & 38.0 & 1 & 35.1 & 38.0 & 40.3 & $37.7-38.5$ & \\
\hline & Intervention I & 32 & 37.9 & 1 & 35.5 & 37.9 & 40.5 & $37.7-38.2$ & 0.34 \\
\hline & Intervention II & 32 & 38.1 & 0.8 & 36.9 & 38.1 & 40.5 & $37.6-38.7$ & 0.9 \\
\hline \multirow{3}{*}{165} & Control & 33 & 37.9 & 1 & 35.0 & 37.8 & 40.1 & $37.8-38.5$ & \\
\hline & Intervention I & 32 & 37.9 & 1 & 36.1 & 37.9 & 41.2 & $37.5-38.3$ & 0.89 \\
\hline & Intervention II & 32 & 38.1 & 0.9 & 36.7 & 38.0 & 40.5 & $37.7-38.4$ & 0.54 \\
\hline \multirow{3}{*}{180} & Control & 33 & 37.9 & 1 & 35.1 & 38.0 & 40.1 & $37.5-38.5$ & \\
\hline & Intervention I & 31 & 37.8 & 1 & 35.7 & 37.9 & 40.1 & $37.6-38.0$ & 0.46 \\
\hline & Intervention II & 32 & 38.0 & 0.9 & 36.6 & 38.0 & 40.4 & $37.7-38.3$ & 0.92 \\
\hline
\end{tabular}

"Standard deviation (SD); " 95\% confidence interval (CI 95\%); “” Mann-Whitney.

\section{DISCUSSION}

This study tested the two most used methods in the nursing environment (ice pack and warm compress associated with antipyretic) in adults and children for the treatment of fever. Patients who received Intervention I (ice pack associated with antipyretic) had a tympanic temperature higher than $38.3^{\circ} \mathrm{C}$ for only 45 minutes after receiving treatment.

In critically ill patients, thermoregulation is usually compromised since factors such as hemodynamic instability, neurological disorders and changes in metabolic rate affect thermal homeostasis, as well as the hospitalization itself that causes changes in the circadian cycle. Despite its adaptive value, the relationship between the occurrence of fever and increased morbidity in critically ill patients is not described in literature, considering that studies are still incomplete and controversial ${ }^{(1,13)}$. It is known that the fever response may be dangerous for patients suffering from cardiopulmonary diseases or sepsis, which can enhance neurological damage, cerebral edema, cardiac ischemia and tissue hypoxia ${ }^{(7)}$.

Therefore, it should be taken into consideration that with the subsequent increase in oxygen consumption due to fever, the respiratory quotient and the cardiac output add a significant load on the clinical status of critically ill patients who may be unable to have their compensatory mechanisms stimulated for the increased metabolic demand ${ }^{(14)}$. Thus, the use of physical methods for cooling the body temperature often occurs in attempt to reduce clinical complications, which confers benefits to antipyretic therapy of hospitalized patients in the $\operatorname{ICU}^{(7,15)}$.

A randomized controlled trial with 200 patients diagnosed with septic shock admitted to ICU assessed whether applying a cooling blanket for body temperature to control fever reduces the use of vasopressor medication and mortality rates. Among the 101 patients who received the physical method, a reduced need for vasopressor usage was identified 
in $34 \%$ compared to $19 \%$ among patients who did not receive treatment $(\mathrm{p}<0.001)^{(16)}$.

In contrast to the antipyretic medication which inhibits fever development by reducing the hypothalamic set point, physical methods reduce the body temperature by increasing the temperature gradient between the body and the environment, promoting heat loss by conduction and convection mechanisms ${ }^{(2)}$. Thus, the adverse effects observed in using physical methods include shivering, vasoconstriction, vasospasm of the coronary arteries and rebound hypothermia, which should also be the focus of attention of the nursing team ${ }^{(4,17)}$.

Studies comparing the application of warm compresses and prescribing a warm bath for children to help in reducing the body temperature of those with fever, either alone or combined with antipyretic versus only antipyretic administration $^{(5)}$ can be found in the literature. One study compares the efficacy of a thermal blanket using convection current cooling system versus an air cooling system with water versus using an antipyretic to lower the body temperature of adult patients with an infectious source of fever and admitted to the $\mathrm{ICU}^{(4)}$. However, studies with experimental design on this theme are scarce, and so the present study contributes to knowledge in this area; to the extent in which nursing care for patients with high body temperatures were tested, and especially physical methods in applying warm compresses and ice packs.

Although a statistical significance between the treatments was not found, an effect size of average magnitude was identified for Intervention I and a small magnitude for Intervention II. This result demonstrates that the use of these methods is effective in the practice, and therefore has clinical relevance; it was observed that applying an ice pack associated with antipyretic has a greater effect on reducing tympanic temperature.

It must be considered that the present study was conducted in two ICUs of a single country and with a population of critically ill patients treated at the same public health institution with infrastructure specificities, especially regarding environmental air cooling. Furthermore, the prescribed and implemented antipyretic for treating fever is not commonly used in hospitals of several other countries. Thus, the results should be used with caution, since generalizations for institutions with different health care models and different clinical profiles in relation to the sample cannot be established.

In clinical research, the evaluation of clinical relevance is crucial to simplify the transfer of knowledge to practice.
Therefore, its importance in biological terms should not only be judged by statistical tests, but also by professionals who will apply the results found in studies into practice. It is up to professionals to guide their practice according to the knowledge available to them, coupled with the new evidence, being aware of the importance of the object being studied ${ }^{(11)}$.

The clinical significance of using physical methods such as antipyretic adjunctive therapy in adult patients admitted to the ICU was also investigated in intensive care units in Australia and New Zealand. The study described fever management of critically ill patients with sepsis without neurological injury. It was found that $64 \%$ of the critical care nurses reported the association of antipyretic to physical methods as the first choice of care for adult patients with fever, considering the positive clinical experience with this method, while only $13 \%$ reported a preference for using isolated methods ${ }^{(18)}$.

Thus, application of physical methods associated with antipyretic administration should be considered, with it being important to recognize that statistical significance cannot be used as a synonym of clinical significance; as a result, it may be statistically significant but have no relevance for the practice, so it is important to understand that the results of a study should not be confined to the $p$ values ${ }^{(11)}$.

\section{CONCLUSION}

A reduction in body temperature was observed in the three groups evaluated throughout 180 minutes, but without statistical significance. However, when analyzing the effect size of these interventions in patients with fever, it was found that the studied methods are clinically indicated and their use proved to be effective in care practice.

Body temperature is a very specific variable and decimal differences in the readings can be decisive in the clinical decision to be made. Thus, the care/treatment to be provided to a critical patient with fever should not solely be based on the value of the body temperature being greater than or equal to $38.3^{\circ} \mathrm{C}$ when administering an antipyretic. Clinical signs presented by the patient should also be evaluated and using a physical method must be considered, such as an ice pack for treating a fever, and not only the administration of an antipyretic.

In addition, health professionals should be aware of the adverse effects of both antipyretic and physical methods in reducing the body temperature of patients with fever, and substitute practices based on tradition for practices based on evidence to improve outcomes of the provided care.

\section{RESUMO}

Objetivo: Avaliar o efeito de métodos físicos (bolsa de gelo e compressa morna) na redução da temperatura corporal de pacientes críticos com febre. Método: Ensaio clínico randomizado com 102 pacientes adultos e temperatura timpânica $\geq 38,3^{\circ} \mathrm{C}$ de foco infeccioso, aleatorizados em três grupos: Intervenção I - bolsa de gelo associada a antitérmico; Intervenção II - compressa morna associada a antitérmico; e Controle - antitérmico. A temperatura timpânica foi mensurada em intervalos de 15 minutos durante 3 horas. O efeito das intervenções foi avaliado pelo teste Mann-Whitney e Análise de Sobrevivência. Cálculo do "Effect size" foi procedido. Resultados: Os pacientes dos grupos Intervenção I e II apresentaram maior redução na temperatura corporal. A partir de 45 minutos de acompanhamento o grupo de pacientes que recebeu a Intervenção I apresentou valor da temperatura timpânica inferior a $38,3^{\circ} \mathrm{C}$, os do grupo controle valor menor que $38,3^{\circ} \mathrm{C}$ a partir de 60 minutos e os que receberam a Intervenção II, valor menor que $38,3^{\circ} \mathrm{C}$ 
com 75 minutos de acompanhamento. Conclusão: Não foi encontrada diferença estatística significativa entre as intervenções, porém os pacientes do grupo Intervenção I apresentaram maior redução da temperatura timpânica em relação aos demais grupos. Registro Brasileiro de Ensaios Clínicos: RBR-2k3kbq

\section{DESCRITORES}

Febre; Enfermagem de Cuidados Críticos; Enfermagem Baseada em Evidências; Avaliação de Resultado de Intervenções Terapêuticas; Unidades de Terapia Intensiva.

\section{RESUMEN}

Objetivo: Evaluar el efecto de métodos físicos (bolsa de hielo y compresa tibia) en la reducción de la temperatura corporal de pacientes críticos con fiebre. Método: Ensayo clínico randomizado con 102 pacientes adultos y temperatura timpánica $\geq 38,3^{\circ} \mathrm{C}$ de foco infeccioso, aleatorizados en tres grupos: Intervención I - bolsa de hielo asociada con antitérmico; Intervención II - compresa tibia asociada con antitérmico; y Control - antitérmico. La temperatura timpánica fue medida en intervalos de 15 minutos durante 3 horas. El efecto de las intervenciones fue evaluado por la prueba Mann-Whitney y Análisis de Supervivencia. Se hizo el cálculo del "Effect size". Resultados: Los pacientes de los grupos Intervención I y II presentaron mayor reducción en la temperatura corporal. A partir de 45 minutos de seguimiento el grupo de pacientes que recibió la Intervención I presentó valor de la temperatura timpánica inferior a $38,3^{\circ} \mathrm{C}$; los del grupo control, valor menor que $38,3^{\circ} \mathrm{C}$ a partir de 60 minutos; y los que recibieron la Intervención II, valor menor que $38,3^{\circ} \mathrm{C}$ con 75 minutos de seguimiento. Conclusión: No fue encontrada diferencia estadística significativa entre las intervenciones, sin embargo los pacientes del grupo Intervención I presentaron mayor reducción de la temperatura timpánica con relación a los demás grupos. Registro Brasileño de Ensayos Clínicos: RBR-2k3kbq

\section{DESCRIPTORES}

Fiebre; Enfermería de Cuidados Críticos; Enfermería Basada en la Evidencia; Evaluación de Resultados de Intervenciones Terapéuticas; Unidades de Cuidados Intensivos.

\section{REFERENCES}

1. Nakajima Y. Controversies in the temperature management of critically ill patients. J Anesth. 2016;30(5):873-83.

2. Young PJ, Saxena M. Fever management in intensive care patients with infections. Crit Care. 2014;18(2):206.

3. Kushimoto S, Yamanouchi S, Endo T, Sato T, Nomura R, Fujita M, et al. Body temperature abnormalities in non-neurological critically ill patients: a review of the literature. J Intensive Care. 2014;2(1):14.

4. Lee BH, Inui D, Suh GY, Kim JY, Kwon JY, Park J, et al. Association of body temperature and antipyretic treatments with mortality of critically ill patients with and without sepsis: multi-centered prospective observational study. Crit Care. 2012;16(1):R33.

5. Salgado PO, Silva LCR, Silva PMA, Paiva IRA, Macieira TGR, Chianca TCM. Cuidados de enfermagem a pacientes com temperatura corporal elevada: revisão integrativa. Rev Min Enferm. 2015;19(1):212-26.

6. Young P, Saxena M, Bellomo R, Freebairn R, Hammond N, Haren F, et al. Acetaminophen for fever in critically ill patients with suspected infection. N Engl J Med. 2015;373(23):2215-24.

7. Suzuki S, Eastwood GM, Bailey M, Gattas D, Kruger P, Saxena M, et al. Paracetamol therapy and outcome of critically ill patients: a multicenter retrospective observational study. Crit Care. 2015;19:162.

8. Gozzoli V, Treggiari MM, Kleger GR, Roux-Lombard P, Fathi M, Pichard C, et al. Randomized trial of the effect of antipyresis by metamizol, propacetamol or external cooling on metabolism, hemodynamics and inflammatory response. Intensive Care Med. $2004 ; 30(3): 401-7$.

9. Nettina SM. Prática de enfermagem. 10ª ed. Rio de Janeiro: Guanabara Koogan; 2016.

10. Zhen C, Xia Z, Ya Jun Z, Long L, Jian S, Ju CG, Long L. Accuracy of infrared tympanic thermometry used in the diagnosis of fever in children: a systematic review and meta-analysis. Clin Pediatr. 2015;54(2):114-26.

11. Bosco FA, Aguinis H, Singh K, Field JG, Pierce CA. Correlational effect size benchmarks. J Appl Psychol. 2015;100(2):431-49.

12. lalongo C. Understanding the effect size and its measures. Biochemia Med 2016;26(2):150-63.

13. Saxena MK, Taylor C, Billot L, Bompoint S, Gowardman J, Roberts JA, et al. The effect of paracetamol on core body temperature in acute traumatic brain injury: a randomised, controlled clinical trial. PLoS One. 2015;10(12):e0144740.

14. Schortgen F, Charles-Nelson A, Bouadma L, Bizouard G, Brochard L, Katsahian S. Respective impact of lowering body temperature and heart rate on mortality in septic shock: mediation analysis of a randomized trial. Intensive Care Med. 2015;41(10):1800-8.

15. Young PJ, Bellomo R. Fever in sepsis: is it cool to be hot? Crit Care. 2014;18(1):109.

16. Schortgen F, Clabault K, Katsahian S, Devaquet J, Mercat A, Deye N, et al. Fever control using external cooling in septic shock: a randomized controlled trial. Am J Respir Crit Care Med. 2012;185(10):1088-95.

17. Maekawa T, Yamashita S, Nagao S, Hayashi N, Ohashi Y. Prolonged mild therapeutic hypothermia versus fever control with tight hemodynamic monitoring and slow rewarming in patients with severe traumatic brain injury: a randomized controlled trial. J Neurotrauma. 2015;32(7):422-9.

18. Saxena MK, Hammond NE, Taylor C, Young P, Reade MC, Bellomo R, et al. A survey of fever management for febrile intensive care patients without neurological injury. Crit Care Resusc. 2011;13(4):238-43.

Financial support: Conselho Nacional de Desenvolvimento Científico e Tecnológico (CNPq). Process number. 474134/2010-5. 